\title{
A GCM study of climate change induced by deforestation in Africa
}

\author{
Fredrick H. M. Semazzi ${ }^{1,2, *}$, Yi Song ${ }^{1}$ \\ ${ }^{1}$ Department of Marine, Earth and Atmospheric Sciences and ${ }^{2}$ Department of Mathematics, \\ North Carolina State University, Raleigh, North Carolina 27695, USA
}

\begin{abstract}
In this modeling study we investigated the potential climate change which would result from totally clearing the tropical rain forests in Africa. The primary research vehicle in our investigation was the standard version of the National Center for Atmospheric Research (NCAR) CCM3 global climate model (GCM), with a horizontal resolution of triangular spectral truncation T42 (approximately $2.8^{\circ} \times 2.8^{\circ}$ ). Two separate $10 \mathrm{yr}$ simulations were performedifor each of these the global climatological sea surface temperature field was prescribed. The purpose of the $10 \mathrm{yr}$ simulations was to provide a sufficiently large ensemble whose average minimizes model noise errors. In the control simulation normal vegetation was prescribed. The design of the anomaly experiment was similar to the control run except that the tropical rainforest regions in Africa were replaced by savanna grassland vegetation. The CCM3 GCM successfully simulated the primary features of the seasonal mean climate conditions over Africa. The model results show that replacement of tropical rain forest vegetation with savanna grassland vegetation produces the following climate changes over Africa: (1) Over the deforested region, the model results indicate a significant reduction in areaaveraged rainfall throughout the year. The decrease ranges between 2 to $3 \mathrm{~mm} \mathrm{~d}^{-1}$ during the northern hemispheric summer months, when the region experiences the driest conditions (July to September), and less than $1 \mathrm{~mm} \mathrm{~d}^{-1}$ during the wettest months (autumn and spring). (2) Over southern Africa deforestation results in substantial rainfall reduction over Mozambique and rainfall increase over Botswana, Zambia, the southern region of the Democratic Republic of the Congo, and parts of South Africa. Changes in the trapped Rossby wave train activity generated by the mid-tropospheric latent heating over the tropical forest region are responsible for the continental-scale teleconnection climate response. (3) Over Eastern and Western Africa the impact of deforestation is primarily characterized by a reduction in rainfall, however the adopted GCM T42 resolution may not have been adequate to resolve the large contrasts in terrain and vegetation types. (4) Over the rest of Africa the response is relatively weak.
\end{abstract}

KEY WORDS: Climate change · Deforestation · Climate of Africa $\cdot$ Climate modelling

\section{INTRODUCTION}

As a consequence of its vast size and proximity to the equator, Africa experiences a wide variety of climate regimes, ranging from deserts to tropical rainforests (Nicholson et al. 1988, Krishnamurti \& Ogallo 1989). The poleward extremes of the continent experience winter rainfall associated with the passage of the mid-

*E-mail: fred_semazzi@ncsu.edu dle-latitude synoptic disturbances. Across the Kalahari and Sahara desert regions, precipitation is inhibited by sinking motion virtually throughout the year. In contrast, the equatorial and tropical regions are characterized by abundant precipitation concentrated along the Inter-Tropical Convergence Zone (ITCZ). Since the movement of the ITCZ trails the position of maximum surface heating associated with the north/south displacement of the overhead position of the sun, the near-equatorial regions have 2 rainy seasons while 
most of the other regions of the continent have only 1 distinct rainy period during the year. The climate of Africa is further modified by the presence of orography. The influence of the large-scale mountain barriers is well known; it is essentially characterized by relatively drier conditions to the leeward side, while wetter climate prevails on the windward slopes of the mountains. Evidence suggests that large-scale orography could play an important role in modulating the continental climate (Semazzi 1980a,b, Semazzi \& Sun 1997). For a more comprehensive account of the climatology of Africa we refer the reader to Nicholson et al. (1988) and Krishnamurti \& Ogallo (1989).

Out of nearly 100 countries in the world affected by deforestation and desertification, about half of them are in Africa; this translates to more than $80 \%$ of the African countries (Brown et al. 1990, 1995, and references therein). Although it is generally accepted that the overall rate of the clearing of the tropical forests is about $0.6 \% \mathrm{yr}^{-1}$, large variation exists between different regions of the Africa continent. Ground surveys of tropical forests are now being augmented by airborne sampling methods, such as the use of low-altitude photography, satellite systems, and side-looking radar (Brown et al. 1990). Remotely sensed data have a great deal of promise, but there are many technical problems yet to be resolved. For instance, some state-ofthe-art satellite images can only broadly classify vegetation, and others provide greater resolution but at a smaller scale; thus the cost of obtaining and interpreting meaningful coverage can be prohibitive (Tucker et al. 1984, Malingreau et al. 1989). Some space or airborne systems can be degraded by the frequent cloudiness of the tropics and the smoke from the fires used to clear the forests. Moreover, because deforestation is such a highly charged political issue, even the most impeccable data are subject to considerable differences in interpretation (Matthews 1983, Allen \& Barnes 1985). Nevertheless, it is recognized that the present rates of clearing will probably deplete the forest resources within the next 20 to $30 \mathrm{yr}$. As denser road networks are constructed in the presently relatively inaccessible regions, such as the interior of the Congo tropical rainforest, deforestation will most likely accelerate.

Since the pioneering study of Charney et al. (1977) a large volume of modeling and observational studies have investigated the hypothesis which states that the increase in surface albedo and the reduction in evapotranspiration and surface roughness (Sud \& Smith 1985, Sud et al. 1988, Williams 1990, Nobre et al. 1991) associated with the degradation of vegetation will have a positive feedback on future rainfall. The hypothesis postulates that through these biogeophysical feedbacks an incipient drought can become self-promoting
(Williams 1990). It has been predicted that this mechanism may be partly responsible for the expansion of the sub-Saharan desert border region, thus helping to turn it into a true desert. It has been estimated that complete removal of the Amazon rainforest would have a substantial influence on the regional surface temperature and hydrology (Henderson-Sellers \& Gornitz 1984, Dickinson \& Henderson-Sellers 1988, Shukla et al. 1990, Nobre et al. 1991). Shukla et al. (1990) showed that the turning into agricultural land of the Amazonian tropical forest could result in a suppression of precipitation larger than the corresponding regional reduction in evapotranspiration, implying that the dynamic convergence of moisture from the surrounding regions also would decrease as a result of deforestation. From this and other studies we hypothesize that the ongoing deforestation over the west and central African countries significantly affects the regional moisture balance and leads to irreversible regional climatic changes. More recently Zhang et al. (1996a,b), investigated the deforestation problem by replacing all the world's tropical rainforests with grassland. Their results clarified the important role deforestation could have on global climate in the future. Recent work (Eltahir \& Gong 1996, Zheng \& Eltahir 1998) has shown that the West African monsoon system can be controlled by the meridional gradient of entropy in the boundary layer, a flat (steep) meridional gradient being associated with a weak (strong) monsoon circulation. In particular, numerical experiments (Zheng \& Eltahir 1998) showed that deforestation in the Guinea Coast region could have a greater impact on monsoon circulation strength than desertification in the Sahel area, by reducing this meridional gradient.

The primary goal in the present investigation is to focus on the effect of deforestation on the African climate. We employ a general circulation model (GCM) resolution higher than that used in most previous studies in order to resolve the continental response to deforestation. We stratify the annual cycle into seasons which characterize the main rainy seasons of the primary African climatic zones.

\section{MODEL DESCRIPTION}

The primary research vehicle in this investigation is the standard NCAR CCM3 spectral GCM. The model details may be found in several documents (Bath et al. 1992, Hack et al. 1993, Acker et al. 1996, Bonan 1996, Bryan et al. 1996, Kiehl 1996). Here, we only give a brief outline of the model attributes. CCM3 has a triangular spectral horizontal grid with truncation T42 (approximately $2.8^{\circ} \times 2.8^{\circ}$ transform grid). In the vertical direction the model's atmosphere is stratified into 
18 levels, with a rigid lid at $2.917 \mathrm{mb}$. CCM3 also has the following numerical attributes: a semi-implicit, leap frog time integration scheme; use of the spectral transform method for treating the dry dynamics; application of a bi-harmonic horizontal diffusion operator; and a shape-preserving semi-Lagrangian transport scheme (Williamson \& Rasch 1989) for advecting water vapor, as well as an arbitrary number of other scalar fields (cloud water variables, chemical constituents, etc.). The physics includes use of a delta-Eddington approximation to calculate solar absorption; use of a Voigt line shape for infrared radiative cooling in the stratosphere; inclusion of a diurnal cycle; the incorporation of a finite heat capacity soil/sea ice model; parameterization and treatment of cloud optical properties (Kiehl et al. 1996); non-local treatment of boundary-layer processes; and use of a simple mass flux representation of moist convection.

CCM3 has state-of-the-art treatment of the fluxes between the land surface and the atmosphere, which is important for the present investigation focussing on deforestation induced climate change. The model is coupled to a land surface model (LSM version 1; Bonan 1996) which is a 1-dimensional model of energy, momentum, water, and $\mathrm{CO}_{2}$ exchange between the atmosphere and land. Surface types were derived from Olson et al's (1983) $0.5^{\circ} \times 0.5^{\circ}$ data. Soil colors were taken from the BATS T42 data set for use with the CCM (Dickinson et al. 1993). Sand, silt, and clay data were derived from Webb et al.'s (1993) $1.0^{\circ} \times 1.0^{\circ}$ data set. Inland water data were derived from Cogley's (1991) $1.0^{\circ} \times 1.0^{\circ}$ data for perennial freshwater lakes and swamps/marshes.

The formulation of the LSM accounts for the ecological differences among vegetation types, hydraulic and thermal differences among soil types, and it allows for multiple surface types including lakes and wetlands within a grid cell. Vegetation effects are included by allowing for 12 plant types that differ in leaf and stem areas, root profile, height, leaf dimension, optical properties, stomatal physiology, roughness length, displacement height, and biomass. These 12 plant types are combined to form 28 different vegetated surfaces, each comprised of multiple plant types and bare ground; for example, a mixed broad leaf deciduous and needle leaf evergreen forest consists of patches of broadleaf deciduous trees, needle leaf evergreen trees, and bare ground. Lakes and wetland, if present, form additional patches. Soil effects are included by allowing thermal properties (heat capacity, thermal conductivity) and hydraulic properties (porosity, saturated hydraulic conductivity, saturated metric potential, slope of retention curve) to vary as functions of percent sand and percent clay. Soils also differ in color, which affects soil albedos. Consequently, each grid cell in the domain of interest is assigned a surface type, a fraction covered by lakes, a fraction covered by wetlands, a soil texture (percent sand, percent silt, percent clay), and a soil color. In coupling to the atmospheric model, the LSM provides to the atmospheric model, at every time step, surface albedo (direct beam and diffuse for visible and near-infrared wavebands), upward longwave radiation, sensible heat flux, latent heat flux, water vapor flux, and surface stresses. The atmospheric model provides to the LSM, at every time step, incident solar radiation (direct beam and diffuse for visible and near-infrared wavebands), incident longwave radiation, convective and large-scale precipitation, and lowest model level temperature, wind, specific humidity, pressure, and height.

Two model simulations were performed to study the sensitivity of the African continent seasonal and annual climate response to the replacement of the tropical rainforest vegetation by savanna grassland (Fig. 1). The purpose of imposing such a drastic modification in vegetation in the anomaly experiment is to study the upper bounds of climate change that could be expected from the deforestation over Africa. We recognize that the present level of observed deforestation is more modest than the scale depicted in Fig. 1. It is widely noted that in Africa mature forest is being largely replaced by a mosaic of re-growth forest and shifting agriculture, which is different from the situation in the Amazon, where extensive agricultural colonization is occurring (Gurney et al. 1993).

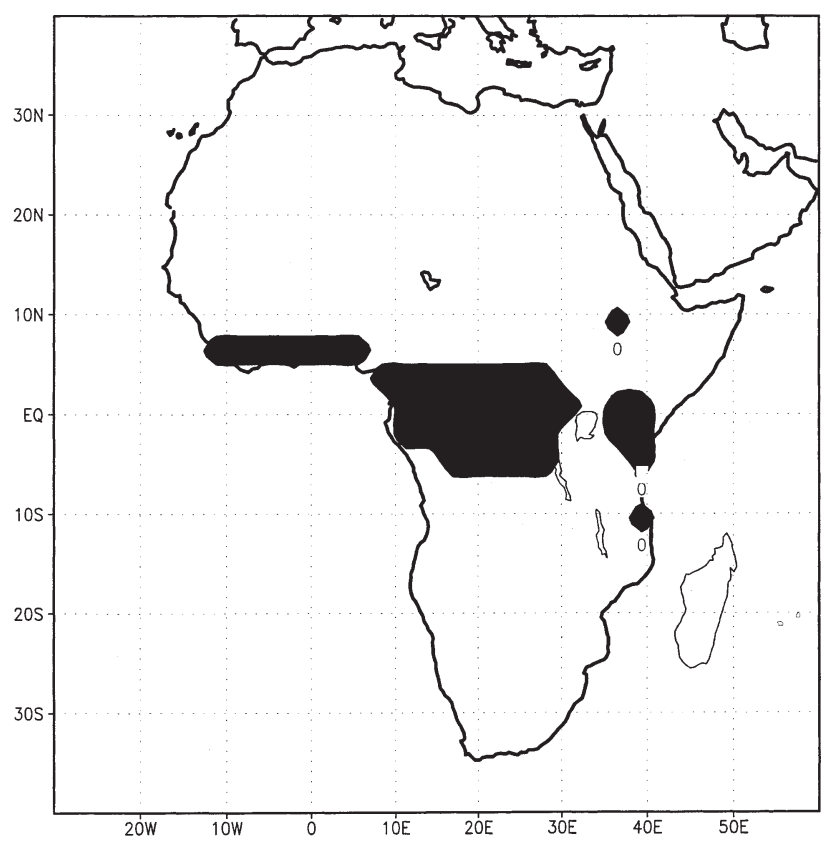

Fig. 1. Deforested region. The forest vegetation consists of a tropical broadleaf evergreen tree type, while the deforested region (in black) is savanna type characterized by interrupted woods 
The forest vegetation consists of a tropical broadleaf evergreen tree type (type 10 in the LSM computer code), while the deforested region is characterized by interrupted woods and a savanna type of vegetation (type 12 in the LSM computer code). A climatological sea-surface temperature (SST) data set archived at NCAR is used to prescribe the lower boundary conditions over the oceans in the model. In each run the model is integrated for $10 \mathrm{yr}$, and the numerical integrations start from the same initial conditions, where the orbital parameters required for computing the solar zenith angle and the initial conditions correspond to the middle of October.

\section{INTRASEASONAL VARIABILITY}

The monthly evolution of the simulated rainfall was examined by considering latitude and longitude cross-

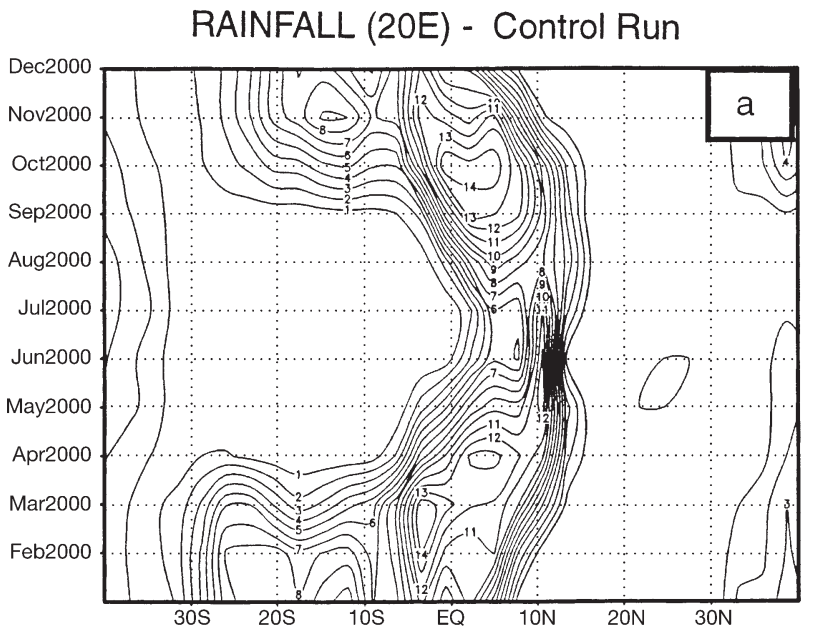

RAINFALL (at equator) - Control Run

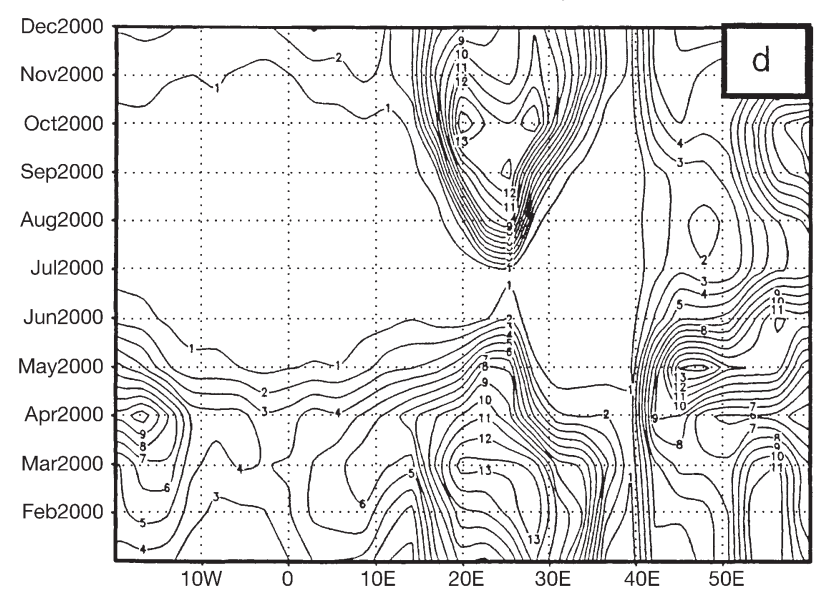

sections through the center of the Congo tropical rainforest, along the $20^{\circ} \mathrm{E}$ meridian and the equator, respectively. Fig. 2a shows that the model simulates realistic migration of the rainfall belt in the meridional direction. The near-equatorial region exhibits rainy conditions nearly throughout the year, with 2 maxima in March-April and October. The lowest rainfall conditions occur in June and July. The southern latitudes have 1 main rain season, which extends from December through February. Over the northern latitudes corresponding to west Africa and the Sahel, the occurrence of the rainy season during the months of the northern hemispheric summer is realistically reproduced, although the latitudinal limit of the rain belt does not extend far enough to the north as observed. Within the longitudinal $\left(10^{\circ}\right.$ to $\left.30^{\circ} \mathrm{E}\right)$ band where deforestation mainly occurs in the model, the 2 rainfall maxima in March and October are clearly evident. July is the only month almost void of rainfall.

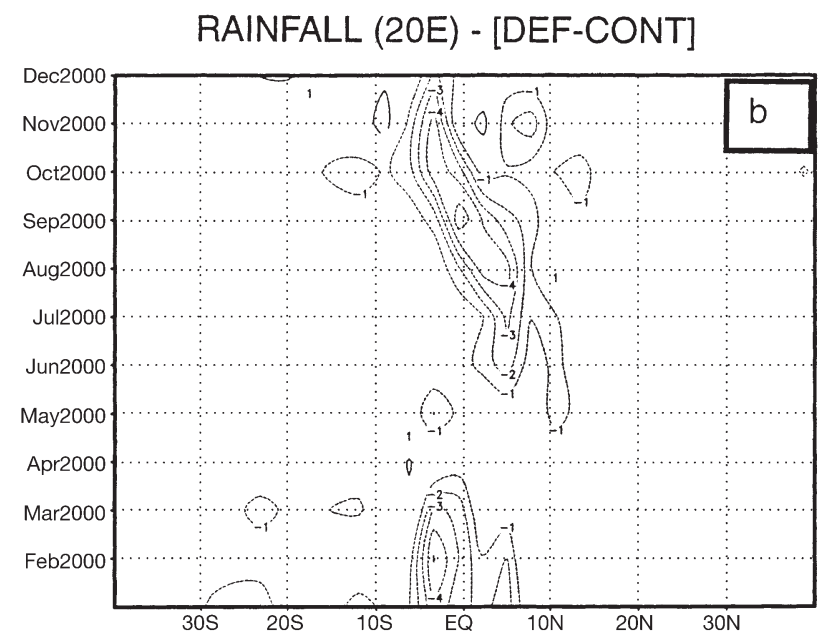

RAINFALL (at equator) - [DEF-CONT]

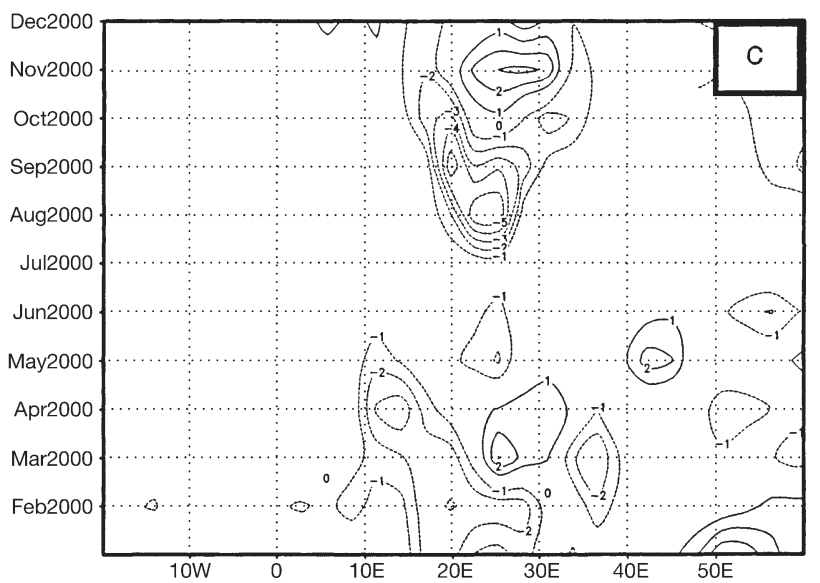

Fig. 2. (a,b) Time-latitude cross-section of rainfall $\left(\mathrm{mm} \mathrm{d}^{-1}\right)$, (a) for the control run and (b) for the deforestation minus control model output, along $20^{\circ} \mathrm{E}$. (c,d) Time-longitude cross-section of rainfall, (c) for the control run and (d) for the deforestation minus control model output, along the equator 
Deforestation results in a significant reduction in the rainfall, with the axis of minimum rainfall exhibiting south-north migration between $10^{\circ} \mathrm{S}$ and $10^{\circ} \mathrm{N}$; the latter is thus mainly confined to the region of deforestation. The reversal in the sign of the anomaly pattern in Fig. 2c indicates that deforestation results in a delayed onset of the September-November rain season. Similar behavior is noted for the February-April rain season, although to a lesser extent. Over the deforested region in the Congo, maximum reduction in rainfall occurs during the driest months of the year, June through September (Fig. 3a). This period corresponds

a RAINFALL (mm/day) - DEF(solid); CONT(dashed)
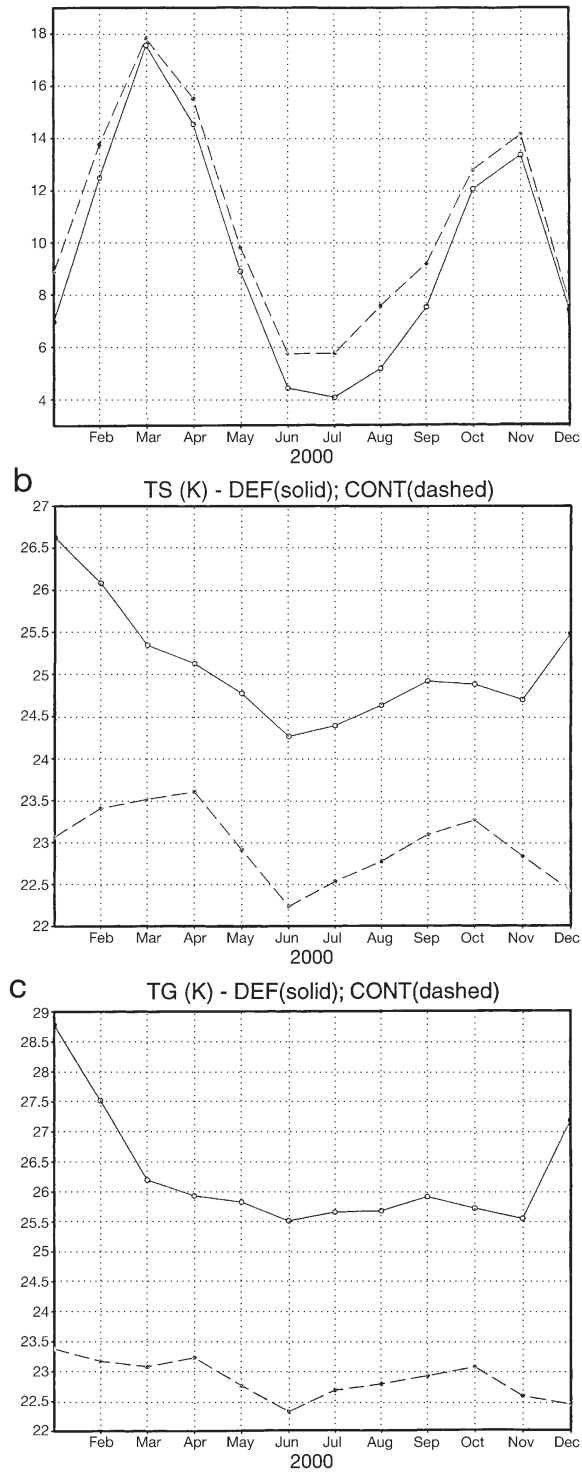

Fig. 3. Annual evolution of (a) rainfall $\left(\mathrm{mm} \mathrm{d}^{-1}\right)$, (b) surface air temperature $(\mathrm{K})$, and $(\mathrm{c})$ ground temperature $(\mathrm{K})$. Area averaging is performed over the primary deforested region $\left[10^{\circ}-30^{\circ} \mathrm{E}, 5^{\circ}-5^{\circ} \mathrm{N}\right]$, the Congo tropical rain forest. Solid lines: deforestation experiment; dashed lines: control run to the lowest surface and ground temperatures of the year (Fig. 3b,c), when the overhead position of the sun is furthest away from the equatorial belt. However, what seems to be even more significant is that this period is also associated with minimum increase in temperature compared to the rest of the year. Inspection of the primary factors (Fig. 4) that contribute to the regional hydrological balance indicates that this period is unique compared to the rest of the year, because it experiences a net loss of moisture through horizontal moisture flux divergence in the case of the deforestation run. For the other seasons, moisture flux convergence is positive irrespective of whether deforestation occurs or not. For all the 4 seasons, the replacement of the tropical rainforest with savanna grassland vegeta-
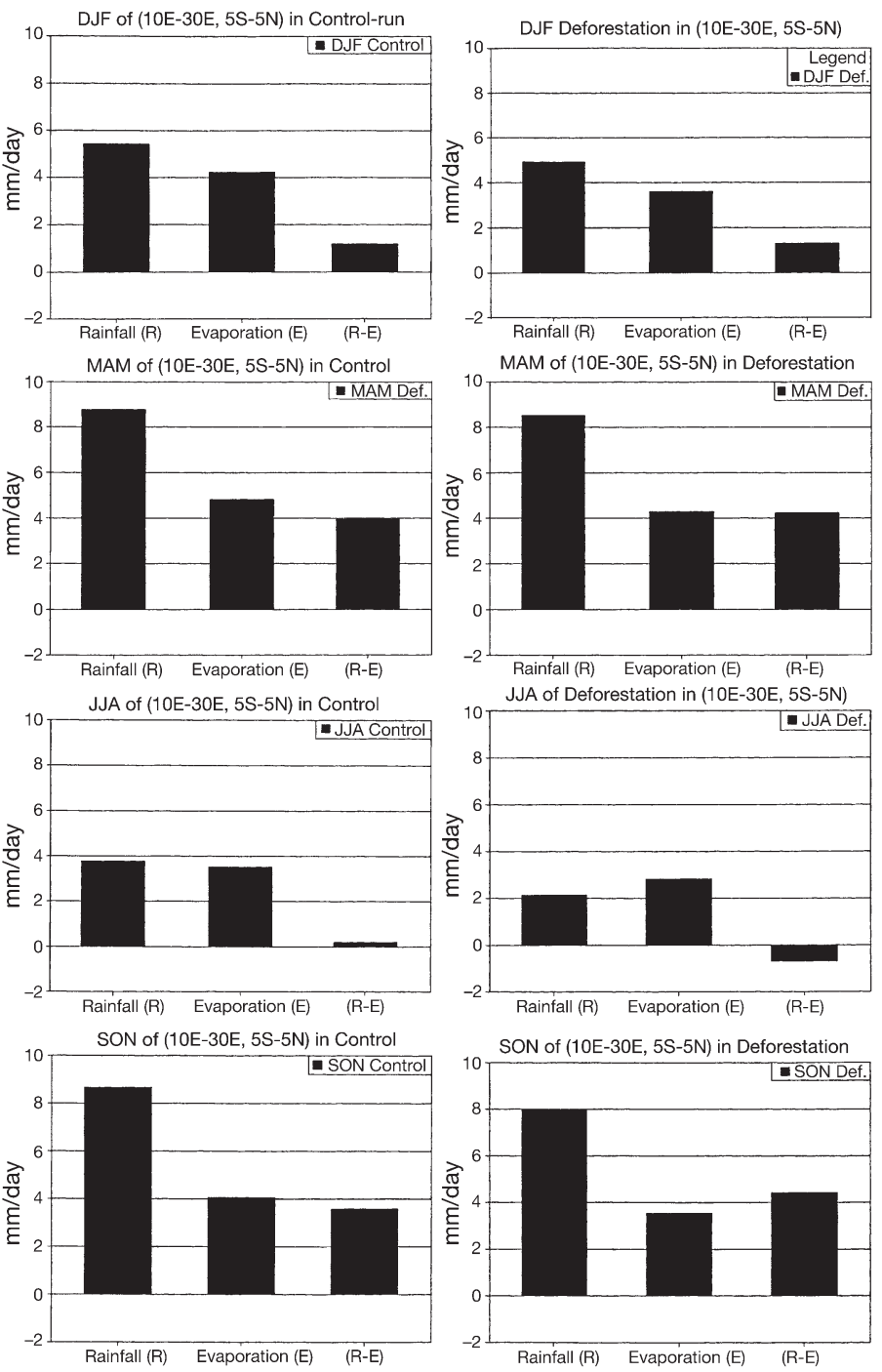

Fig. 4. Seasonal average rainfall (R), evaporation (E), and R-E averaged over the primary deforestation region $\left(10^{\circ}-30^{\circ} \mathrm{E}\right.$, $5^{\circ}-5^{\circ} \mathrm{N}$ ) shown in Fig. 1. DJF: December-February; MM: March-May; JJA: June-August; SON: September-November 
tion results in a suppression of precipitation larger than the corresponding reduction in evapotranspiration, implying that the dynamical horizontal convergence of moisture from the surrounding regions would also decrease as a result of deforestation. This outcome is consistent with similar studies conducted in the past to clarify the potential climate impacts of the Amazonian deforestation (Shukla et al. 1990).

\section{SEASONAL VARIABILITY}

We stratified the year into 4 equal segments, which are normally used to study seasonal climate variability of Africa. These seasons are: December-February
(DJF), March-May (MAM), June-August (JJA), and September-November (SON). Fig. 5 shows the model results for the control run for each of the 4 seasons, and Fig. 6 gives the corresponding rainfall patterns for the deforestation run. Both the control and deforestation runs yield similar rainfall patterns. The corresponding rainfall patterns are not presented here because they have been discussed comprehensively in other studies (Semazzi et al. 1996, Goddard \& Graham 1999, and others). The model faithfully reproduces the migration of the rainfall regimes during the annual cycle. Over complex terrain, such as eastern Africa, the T42 resolution of CCM3 may be too coarse to resolve such important features as, the maximum rainfall over the Ethiopian Highlands. In such cases, it may be neces-
RAINFALL-DJF (CONT)

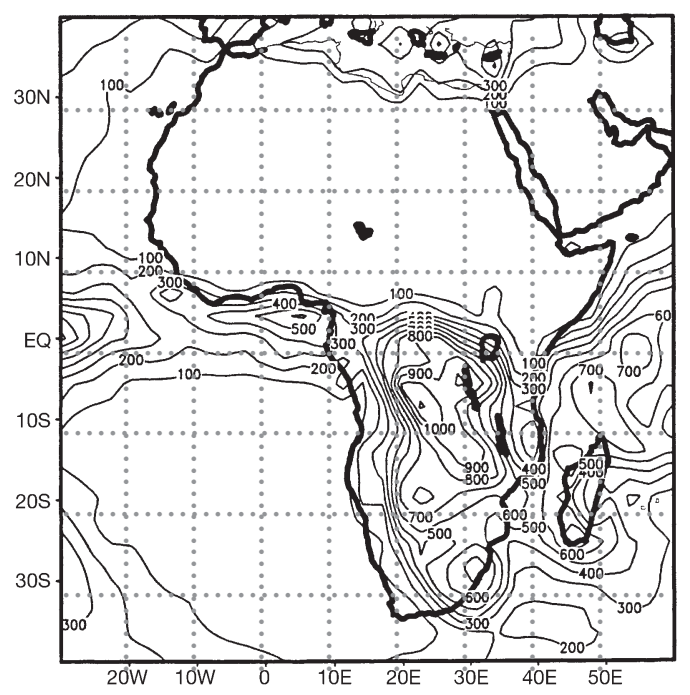

RAINFALL-SON (CONT)

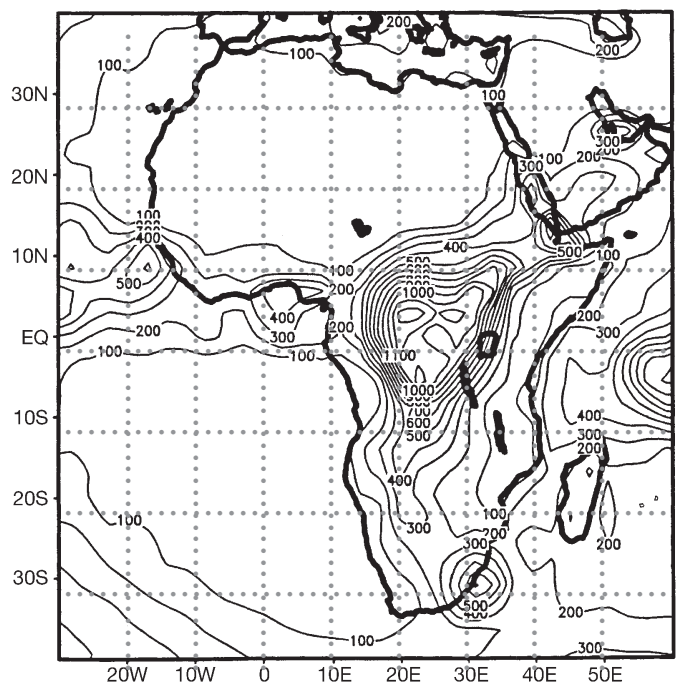

RAINFALL-MAM (CONT)

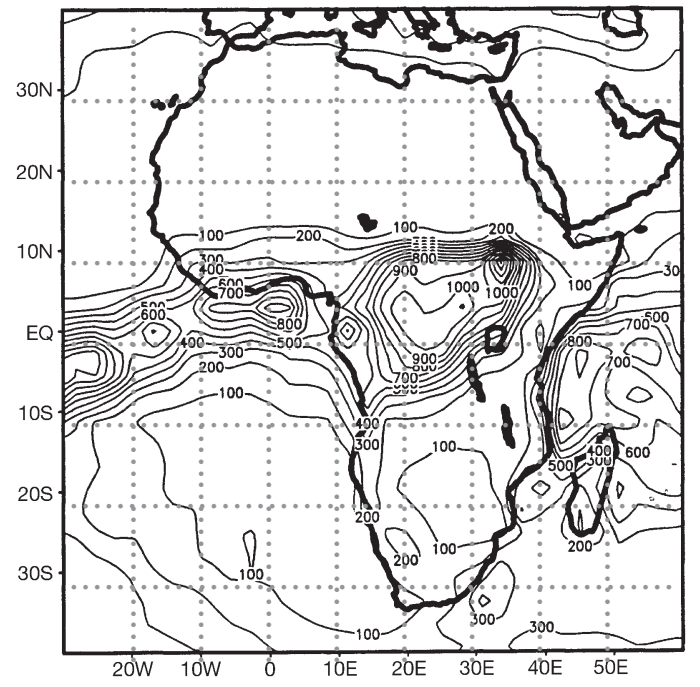

RAINFALL-JJA (CONT)

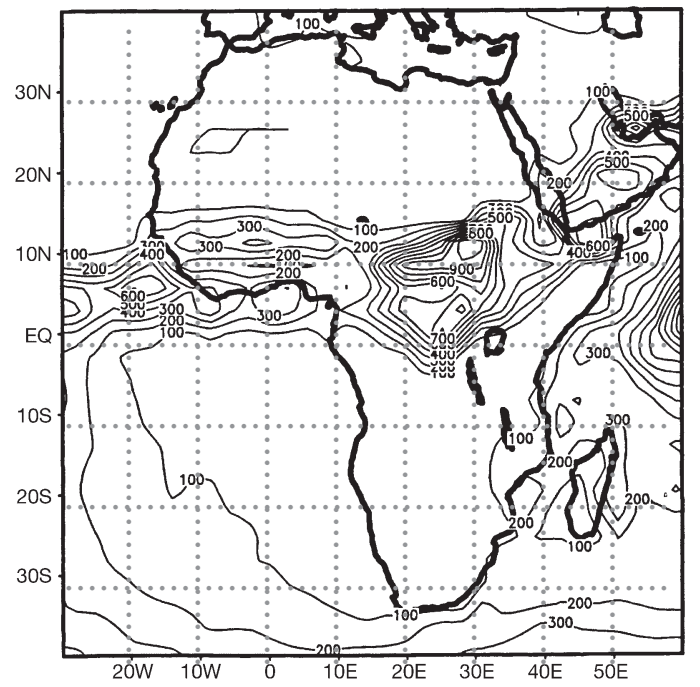

Fig. 5. Total seasonal rainfall $(\mathrm{mm})$ averaged over the $10 \mathrm{yr}$ model simulation period for the control run 

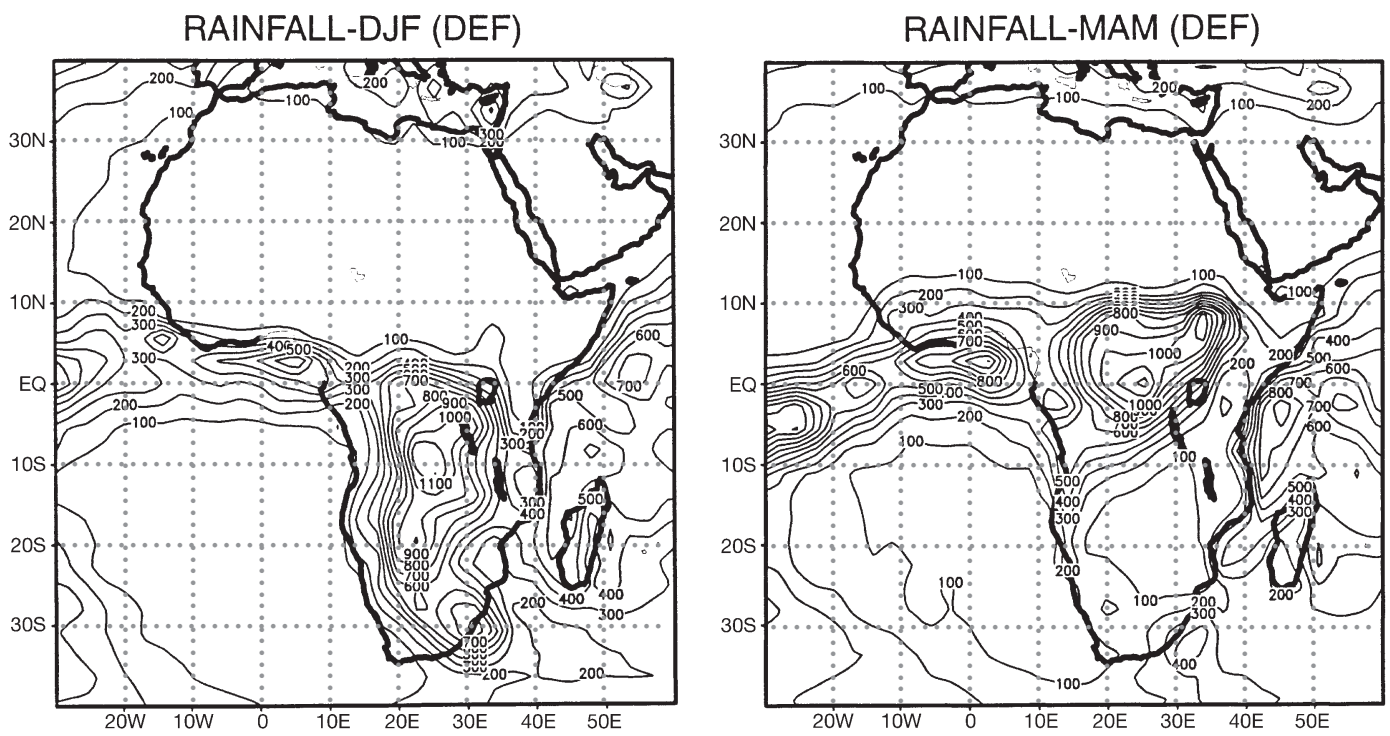

RAINFALL-SON (DEF)
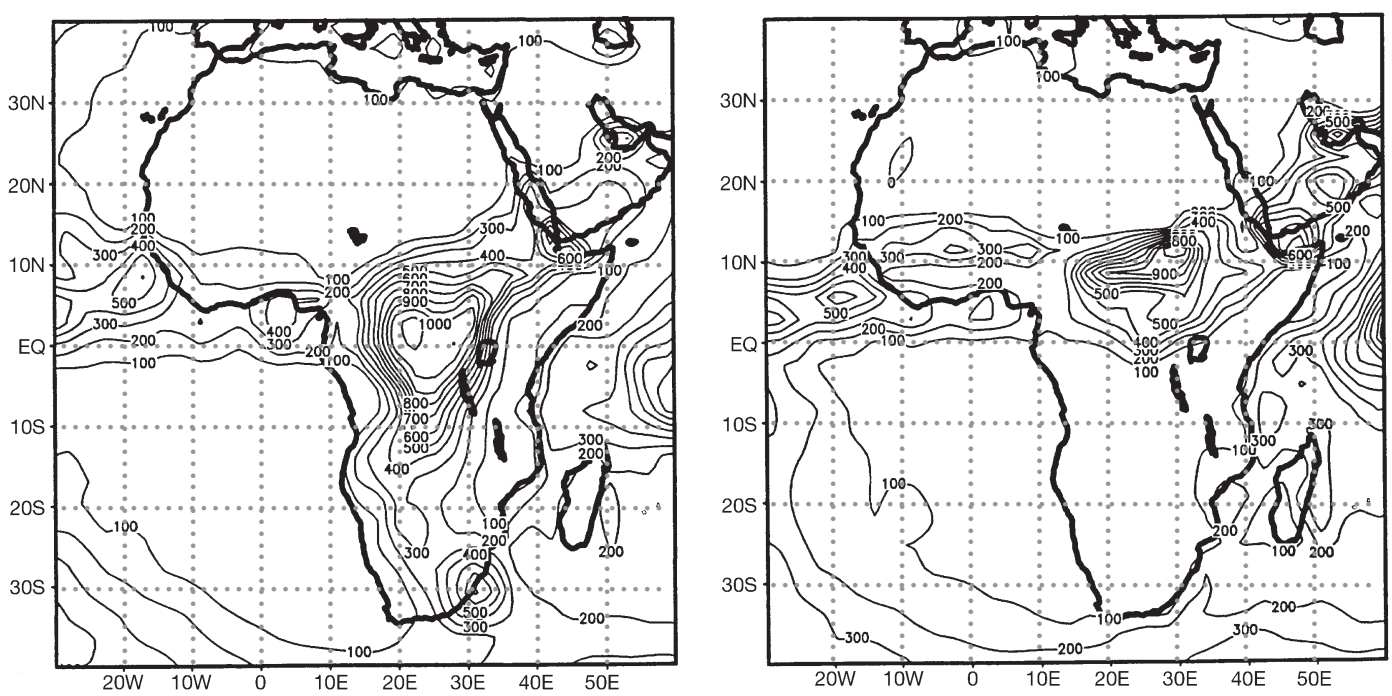

Fig. 6. Total seasonal rainfall (mm) averaged over the $10 \mathrm{yr}$ model simulation period for the deforestation run

sary to adopt the nested model approach (Semazzi et al. 1993, Sun et al. 1999a,b).

Fig. 7 shows the seasonal rainfall differences between the control and deforestation simulations. Over the deforested region the rainfall deficits occur throughout the year. In MAM, JJA, and SON the rainfall anomaly patterns are confined to the region of deforestation. However, DJF is distinctly different from the rest of the seasons. The rainfall deficits over the near-equatorial region are accompanied by a wave of alternating rainfall centers downstream from their embryonic region over central Africa, where most of the deforestation is imposed in the model.

We believe that the wave-like pattern in the rainfall depicted in Fig. 7 is associated with the suppression of
Rossby wave trains (Hoskins \& Karoly 1981, Kalnay \& Helem 1981, Kalnay et al. 1986), itself associated with mid-tropospheric latent heating due to tropical convection over the Congo tropical rainforest. The anomaly pattern manifests itself in the form of regional teleconnection and affects regions remote from the deforested area. Over southern Africa, deforestation results in a reduction in rainfall over Mozambique, and an increase over Botswana, Zambia, the southern region of the Democratic Republic of Congo, and parts of South Africa. Changes in the activity of trapped Rossby wave trains generated by the mid-tropospheric latent heating over the tropical forest region are responsible for this continental teleconnection climate response. 

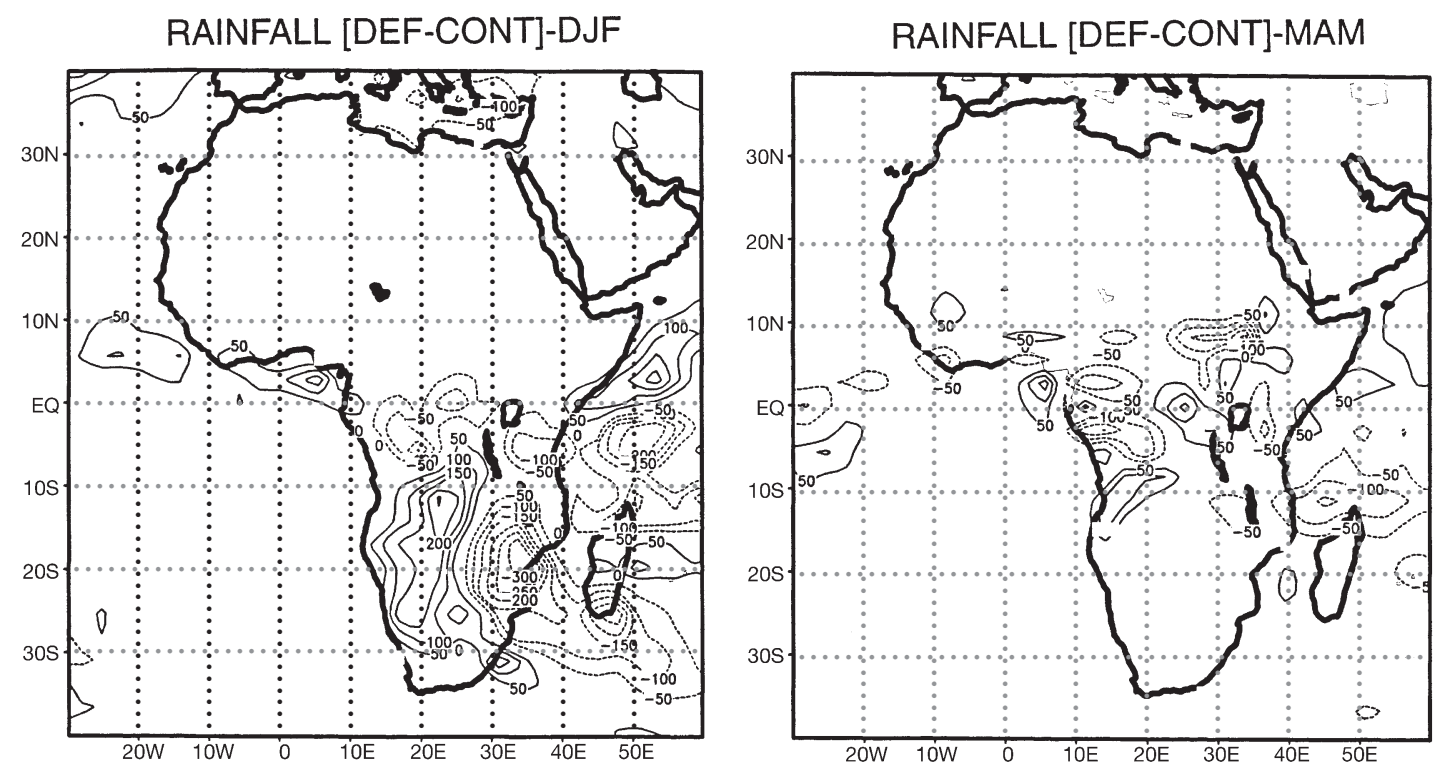

\section{RAINFALL [DEF-CONT]-SON}
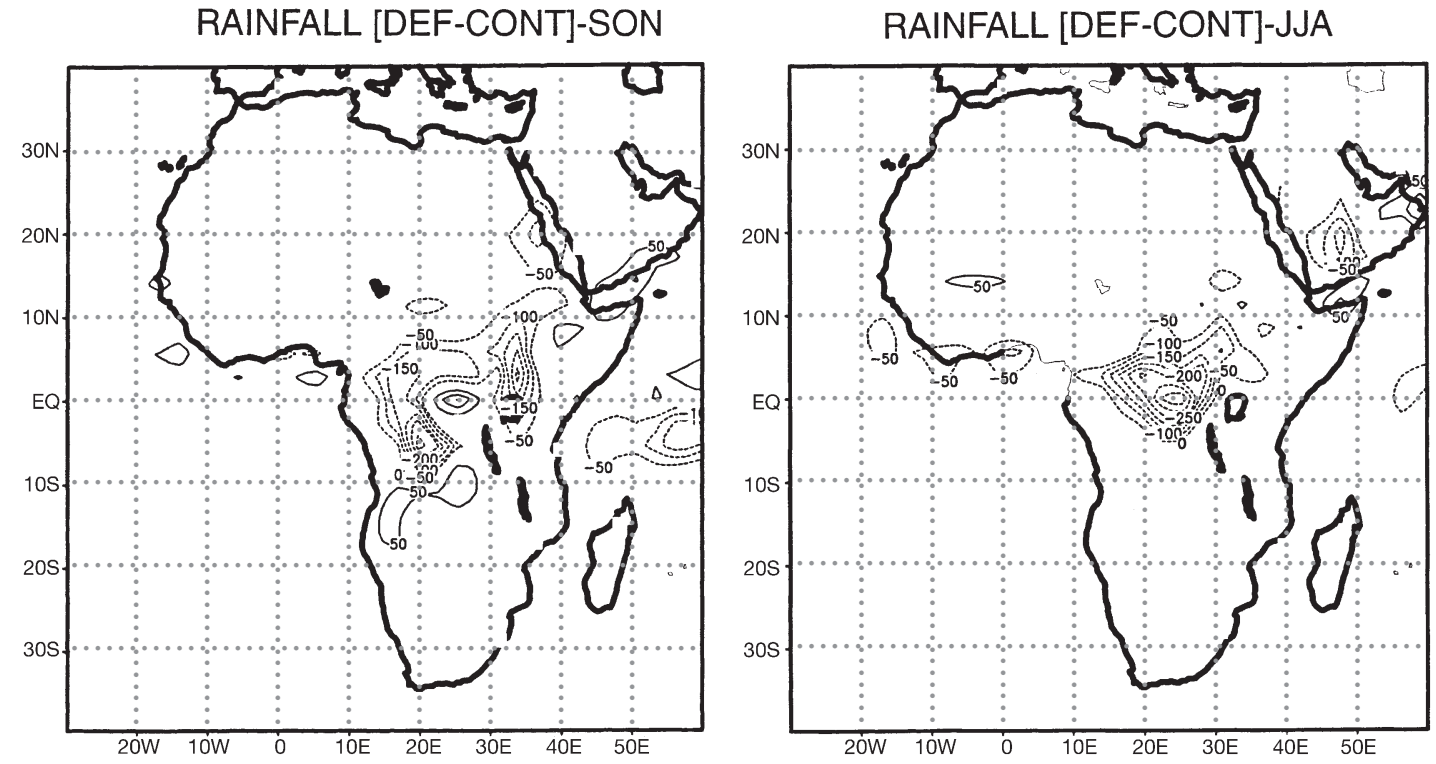

Fig. 7. Total seasonal rainfall $(\mathrm{mm})$ averaged over the $10 \mathrm{yr}$ model simulation period for the deforestation minus control model output

Fig. 8 displays the model simulated geopotential anomaly pattern (derived from the pressure field) at the $200 \mathrm{mb}$ pressure level. The presence of a high pressure center in the upper levels of the atmosphere seen over southern Africa would correspond to lowlevel off-shore circulation away from Mozambique toward Madagascar. This flow pattern would suppress the supply of moisture from the Indian Ocean and support the rainfall deficits observed in Fig. 7. A schematic of the trapping of the short Rossby waves and the escape of the long Rossby waves to the higher latitudes is depicted in Fig. 9. The embryonic region for both kinds of disturbance is located to the north of the waves and it extends from the tropical forest to the region of the location of the ITCZ during DJF further north, which in turn has been influenced by the replacement of the tropical rainforest. The resulting suppression of rainfall due to deforestation reduces upper-level divergence, which is the primary factor responsible for the generation of waveform disturbances.

Many studies have shown that latent heating associated with tropical convection tends to excite Rossby waves (Kalnay et al. 1986) downstream from the source region. The meridional structure of the mean zonal flow essentially determines the relationship between 


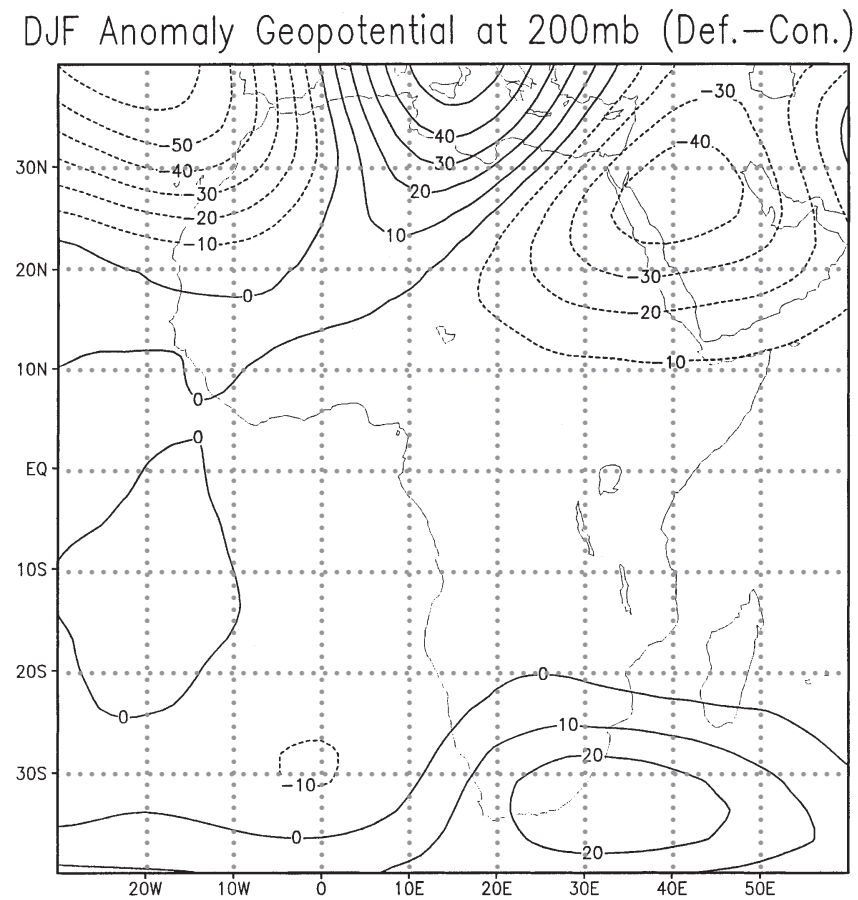

Fig. 8. DJF anomaly geopotential at $200 \mathrm{mb}$ (m) for the deforestation minus control model output

the wavelength and trajectories of the ensuing wave patterns (Hoskins \& Karoly 1981). Splitting of forced Rossby wave trains, usually observed in connection with tropical forcing, arises because long waves propagate freely polewards and eastwards of the poleward flank of the jet. In the atmosphere, the global-scale teleconnection patterns are the poleward propagating planetary Rossby wave trains predicted by theory (Hoskins \& Karoly 1981). In contrast, there have been fewer observational examples of the trapped short waves, which are also predicted by theory, largely because of the limited data coverage over the tropics. For the Southern Hemisphere, Kalnay \& Helem (1981) were among the first to point out the existence of largeamplitude, short-wavelength, stationary Rossby wave trains. These waves, with a dominant scale of wavenumber 7, were prominent over South America during the entire month of January 1979, the first month of the FGGE Special Observing Period (SOP-1). Kalnay et al. (1986) closely reproduced the observed wave trains using a general circulation model and found that convective heating was primarily responsible for their origin.

The streamline pattern in Fig. 10 indicates that the anomaly flow (deforestation minus control) promotes offshore transport of moisture and is thus conducive to drier conditions in the vicinity of the Mozambique Channel and the adjacent inland region. Streamlines are lines which are always parallel to the instantaneous wind velocity, i.e., 'snapshots' of the flow at an instant or over the period for which the average has been obtained. We also note an increase in westerly flow in the vicinity of the deforested region, which could play a significant opposite role in promoting the Rossby wave activity evident in Fig. 7. Linear analysis based on the potential vorticity equation indicates that the dependence of the Coriolis parameter on latitude creates a dramatic difference between easterly and westerly flow over large-scale sources of wave energy (Holton 1972). When westerly flow intercepts the source

\section{Schematic}

\section{DJF Anomaly Geopotential at 200mb (Def.-Con.)}

Fig. 9. Schematic for the DJF anomaly geopotential field at $200 \mathrm{mb}(\mathrm{m})$ depicting changes due to the replacement of the tropical rain for-est with savanna grassland

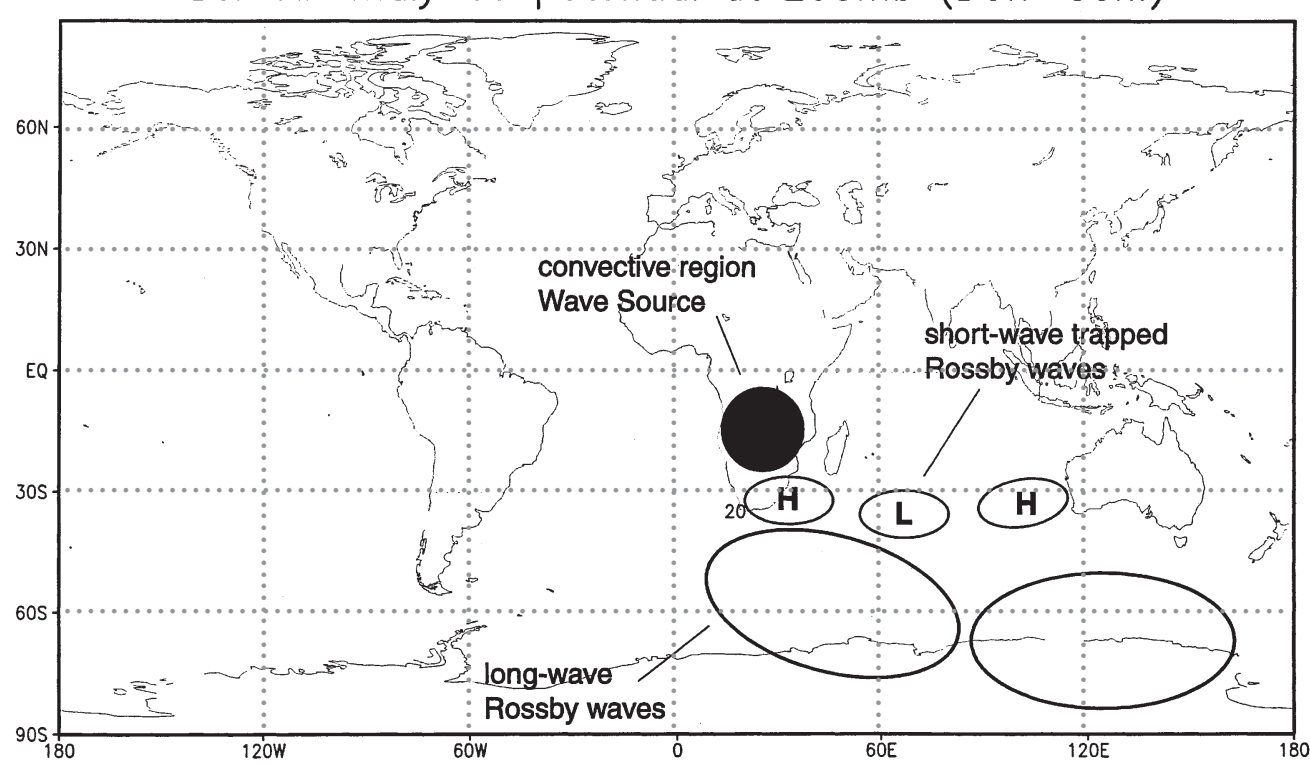




\section{STREAMLINES (DJF) AT 850mb - CONTROL}

a
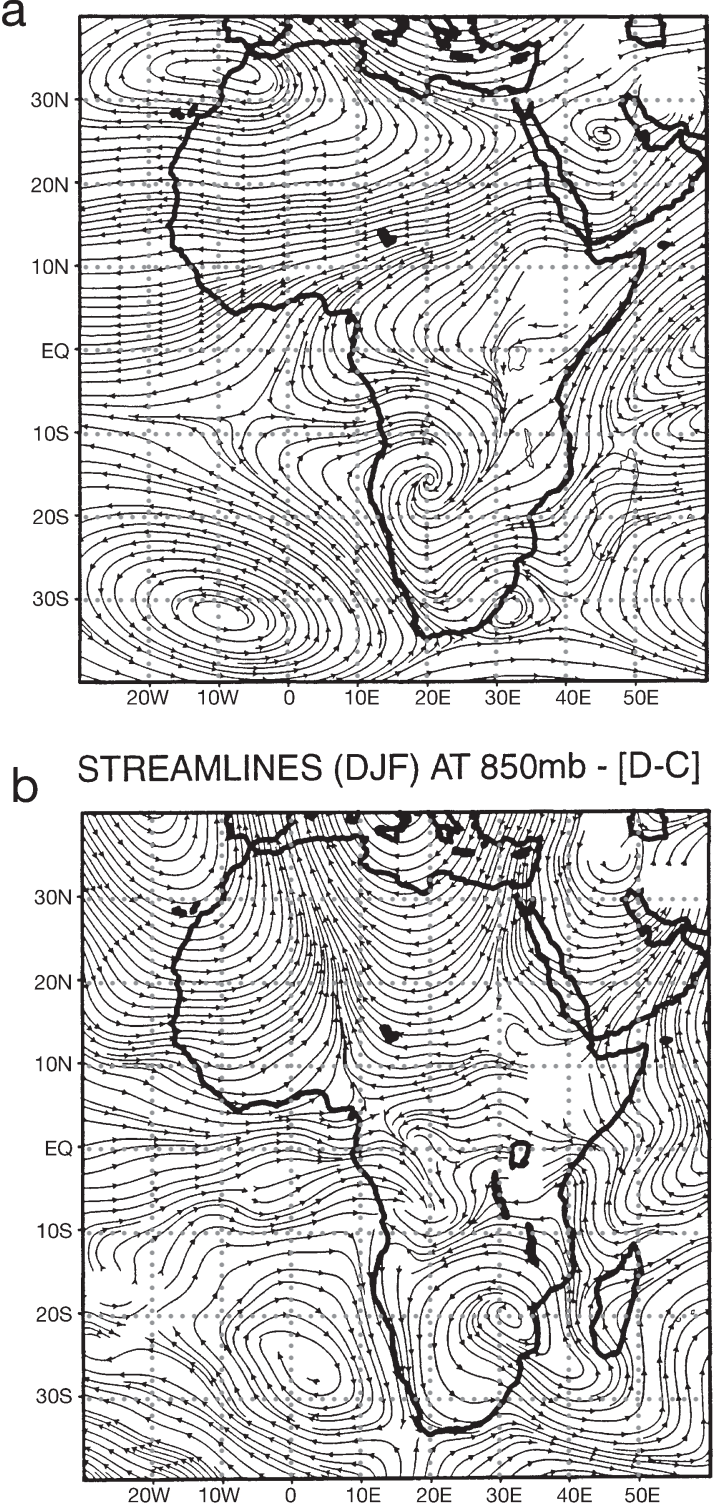

Fig. 10. DJF streamlines at $850 \mathrm{mb}$. (a) Control run and (b) deforestation minus control model output

region it generates wave trains downstream; however, easterly flow results in only localized disturbances in the vicinity of the source.

We believe that the Sahara outflow from the deforested region which is apparent in Fig. 10 is a manifestation of the divergence associated with the reduction in surface roughness due to the deforestation, as predicted by Charney's hypothesis. In the future, this hypothesis should be investigated further.

The apparent opposing roles associated with the increase in westerly flow and the decrease in the midtropospheric diabatic latent heating are not entirely clear based on the present model simulations; they will be the subject of further research investigation to clarify the dynamical reasons for the model results. However, our explanation, based on the role of Rossby wave activity, may have important implications regarding the El Niño/Southern Oscillation (ENSO) teleconnection response over southern Africa. We envisage that the large changes in diabatic latent heating over the central African tropical forest region during ENSO events could be responsible for inducing and maintaining regional climate anomalies through the modulation of the structure and magnitude of trapped Rossby wave trains over the region, similar to the behavior witnessed in the present deforestation study. However, the present design of model experiments is not appropriate to elucidate this hypothesis. If this were the case, then, changes in zonal flow and the intensity of diabatic heating could be important factors in determining the nature of the interannual climate variability over southern Africa in response to ENSO and other forms of ocean forcing scenarios. The wavelength of the resulting wave trains could be a key factor in determining the actual location of the ENSO climate anomalies, thus providing a plausible explanation for the different responses to different ENSO events over southern Africa.

Inspection of major 'outbursts' of convective activity over southern Africa suggests structural characteristics similar to those we have observed in the present model results (R. Washington pers. comm.). This is consistent with our speculation regarding the possible role of shortwave Rossby waves in providing a link between the near-equatorial anomalies in tropical convection and distant locations further downstream over southern Africa. Indeed the persistent 'streaks' of convection usually observed over other tropical regions with widespread organized convection, such as central South America and Indonesia, are potential candidates for supporting similar regional teleconnection climate change in response to deforestation.

\section{ANNUAL MEAN CONDITIONS}

We show in Fig. 11 the simulated annual total rainfall. Comparison with the observed rainfall (Nicholson et al. 1988, Krishnamurti \& Ogallo 1989) indicates that the model successfully simulates the general features of the African climate. In the control run the model successfully reproduces the transition from the wet conditions over the coastal regions to the drier conditions towards the Sahara Desert. The Kalahari Desert and the semi-arid region along the coast of Somalia feature prominently. The difference field, deforestation minus 


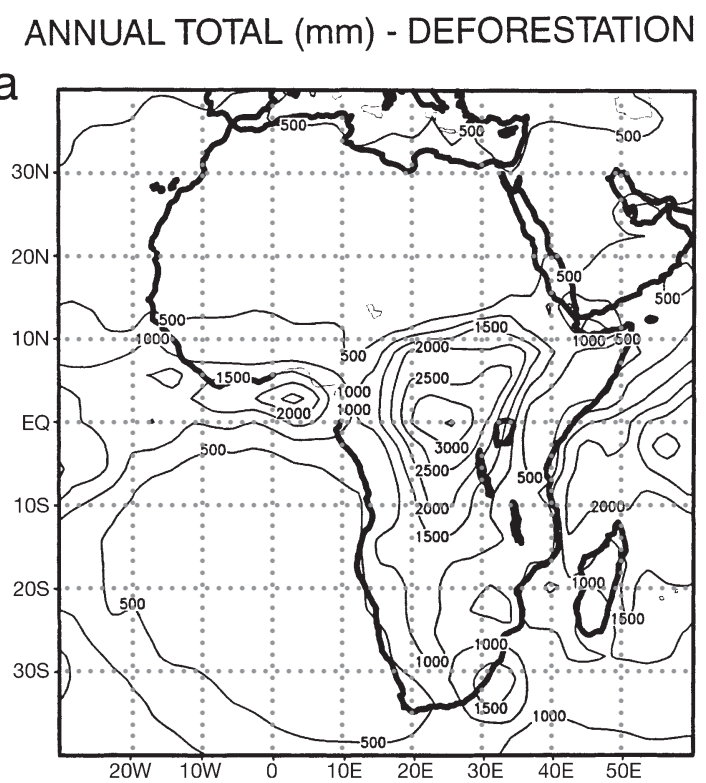

b ANNUAL TOTAL (mm) - CONTROL

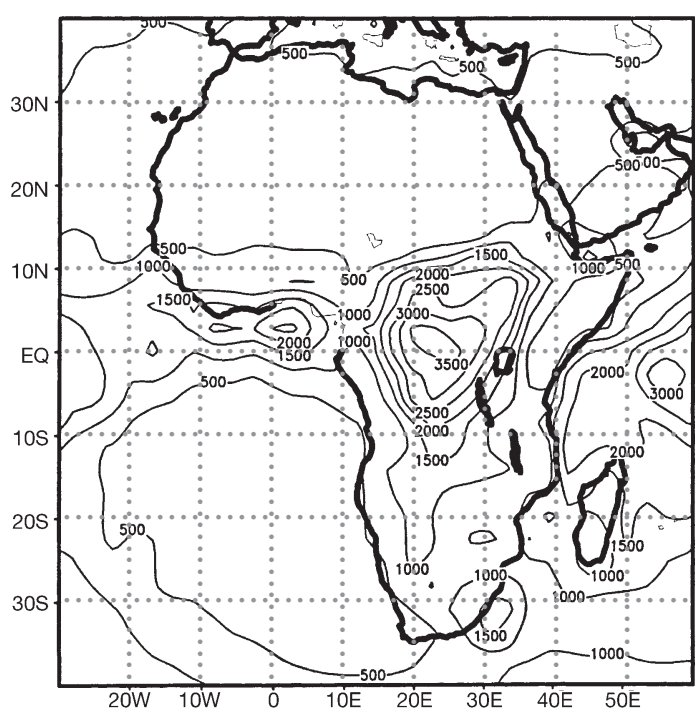

Fig. 11. Annual mean rainfall $\left(\mathrm{mm} \mathrm{yr}^{-1}\right)$ for (a) the deforestation run and (b) the control run

control given in Fig. 12, shows a distinct region of depleted rainfall over the deforested region. The decrease in rainfall is as large as $300 \mathrm{~mm} \mathrm{yr}^{-1}$ over the deforested region. There is some evidence of weak positive anomalies to the south over Namibia and South Africa. Deforestation results in marked changes in surface temperate and ground temperature (Fig. 13) due to the reduction in evapotranspiration associated with deforestation. The ground and surface temperature increases are primarily confined to the deforested regions of West Africa, the Congo Basin, and the eastern Africa evergreen vegetation regions.

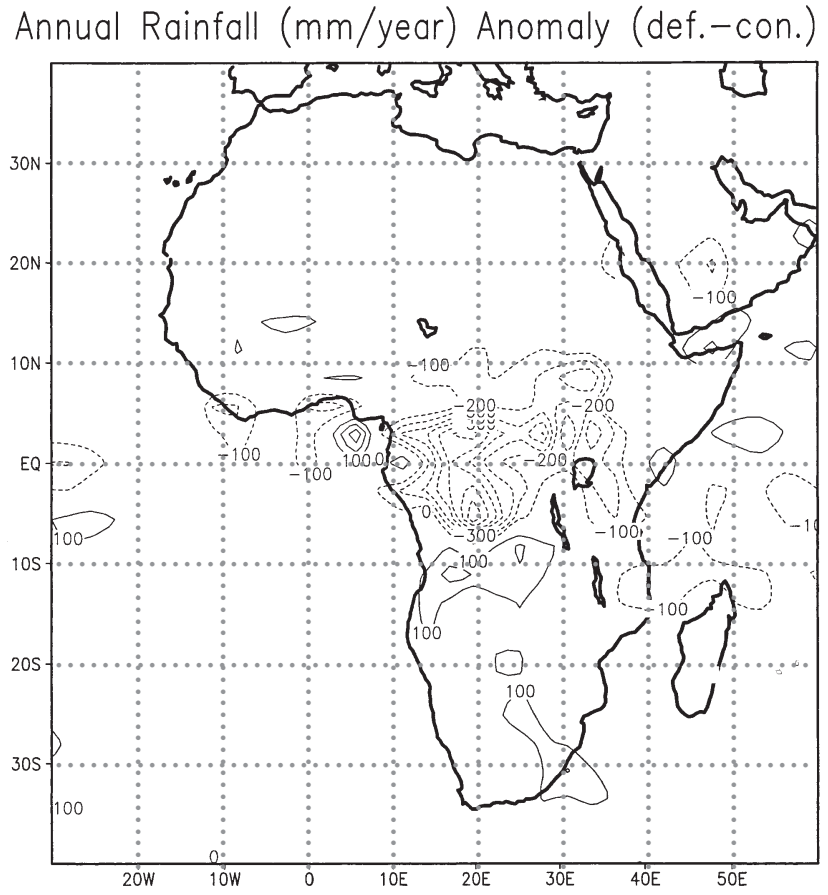

Fig. 12. Annual mean rainfall $\left(\mathrm{mm} \mathrm{yr}^{-1}\right)$ for the deforestation minus control model output

\section{DISCUSSION AND CONCLUSIONS}

We investigated the climatic impact of deforestation in Africa. The primary research vehicle in our investigation was the standard version of the NCAR CCM3 GCM, with a horizontal resolution of triangular spectral truncation T42 (approximately $2.8^{\circ} \times 2.8^{\circ}$ ). Two separate 10-yr simulations based on climatological SST were performed. In the control simulation normal vegetation was prescribed. The design of the anomaly experiment was similar to the control run except that the tropical rainforest regions in Africa were replaced with savanna grassland.

CCM3 successfully simulated the primary features of the seasonal mean climate conditions over Africa. The results show that replacement of tropical rainforest vegetation by savanna grassland vegetation produces the following changes in climate over Africa: (1) Over the deforested region, we observe significant reduction in the rainfall amounts throughout the year. The decrease ranges between 2 to $3 \mathrm{~mm} \mathrm{~d}^{-1}$ during the northern hemispheric summer months, when the region experiences the driest conditions (July-September), and less than $1 \mathrm{~mm} \mathrm{~d}^{-1}$ during the wettest months (Autumn and spring). The changes are as large as 2.5 and $5 \mathrm{~K}$, for the surface and ground temperatures, respectively, consistent with previous studies in the case of the Amazon deforestation studies (Shukla et al. 1990). (2) Over southern Africa deforestation results in 
ANNUAL MEAN TS (K) - ANOMALY (DEF-CONT)

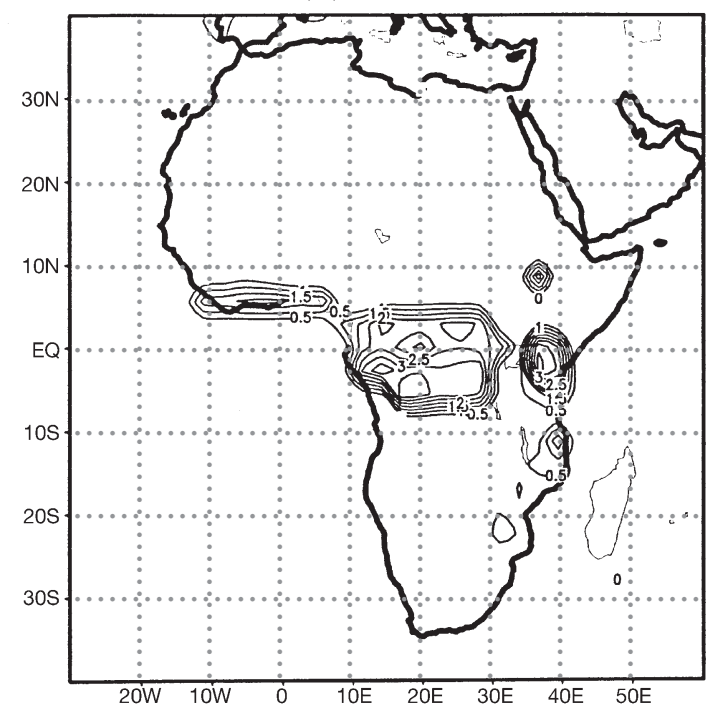

ANNUAL MEAN TG (K) - ANOMALY (DEF-CONT)

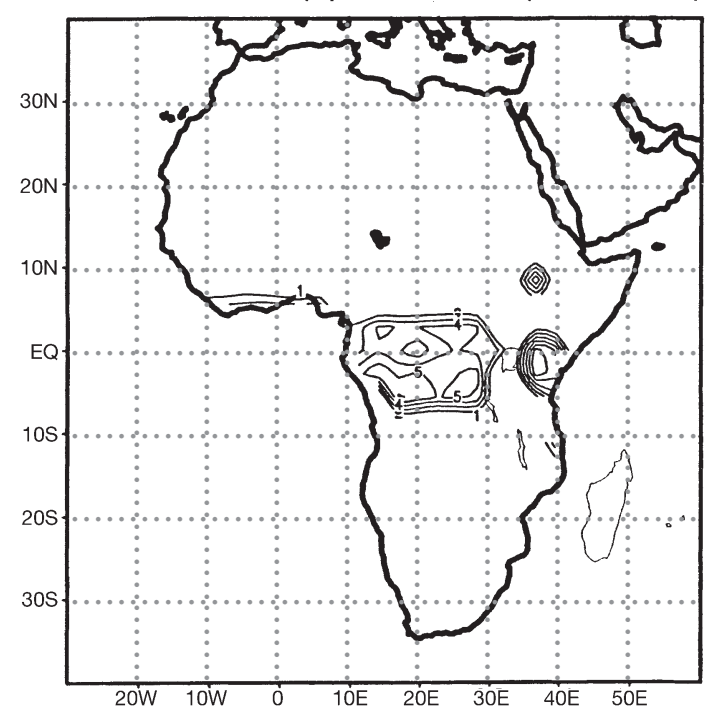

Fig. 13. Change in annual mean temperature (K), deforestation minus control model output, for (a) the surface air temperature and (b) the ground temperature

rainfall reduction over Mozambique and rainfall increase over Botswana, Zambia, the southern region of the Democratic Republic of Congo, and parts of South Africa. Changes in the activity of trapped Rossby wave trains generated by the mid-tropospheric latent heating over the tropical forest region are responsible for this continental-scale teleconnection climate response. (3) Over Eastern and Western Africa the impact of deforestation is primarily characterized by a reduction in rainfall; however, GCM resolution may not have been adequate to resolve the large contrasts in terrain and vegetation types. (4) Over the rest of Africa the response is relatively weak.
The impacts of deforestation simulated by the model for MAM, SON and JJA are not too surprising, as they may generally be deduced from previous studies in which GCMs were employed to study deforestation over other regions. In these seasons, the deforestation results in reduced rainfall primarily confined to the deforested region. However, during SON the model results indicate that deforestation may significantly, if not dramatically, affect distant regions from the region where the rainforest has been cleared. Moreover, the altered circulation over these remote vulnerable regions of Africa could be re-enforced by other sources of climate variability which have not been examined in this paper. For example, we kept the SST for all the oceans fixed in our model simulations. In reality, it is well known that this is not the case. Further modeling investigations should therefore be undertaken to investigate how the impacts of deforestation could be modulated by other factors. Moreover, the reduction in vegetation which was prescribed in the model was rather drastic because it was merely designed to explore the outer bounds of the impacts of deforestation on the climate of Africa. Future investigation should apply the best estimates of deforestation levels in the models to arrive at more realistic results.

We postulate that the role of trapped Rossby waves may also apply to other situations when the tropical convection over Africa is enhanced or suppressed by other factors. In particular, we hypothesize that during ENSO the suppression and/or shifting of the convection through the Walker circulation over Central Africa may trigger a similar mechanism as we have seen in this study. In other words, during the El Niño events, when tropical convection over the rainforest region is suppressed, the conditions correspond to our present results, where the convection was suppressed by deforestation, resulting in a reduction in the rainfall over Mozambique and an increase over Botswana, Zambia, the southern region of the Democratic Republic of Congo, and parts of southern Africa. By the same reasoning, during La Niña, we would expect the opposite conditions to prevail and expect abundant rainfall for Mozambique. Therefore, trapped Rossby wave activity could be one of the potential mechanisms for explaining the observed relationship between ENSO and the interannual variability of the climate over Southern Africa.

The wavelength of the resulting Rossby wave trains could be a key factor in determining the actual location of the ENSO climate anomalies, thus providing a plausible hypothesis for explaining in part the variations in the response to different ENSO events over southern Africa (International CLIVAR Project Office 2000). The 1991-1992 episode in southern Africa illustrates the degree of nonlinearity and the existence of large gaps 
in the understanding of the predictability of the ENSOrelated climate anomalies over southern Africa (IPCC, WAII 1998). In that episode southern Africa experienced the worst drought of the century, rainfall being as much as $80 \%$ below normal (Zinyowera \& Unganai 1993), and seasonal grain production dropped by $60 \%$ below normal. The drought of 1991-1992 was more severe than that during the 1982-1983 and 1997-1998 ENSO events, although the corresponding Pacific SST anomalies were considerably weaker. Our study indirectly suggests that the trapped large-amplitude shortwave Rossby wave trains emanating from the African latent heat source region should be included as one of the key research topics in clarifying the role of and the interaction among the Pacific-Atlantic ENSO teleconnection, the Indian Ocean, the Atlantic Ocean, and the middle-latitude synoptic winter frontal disturbances.

Acknowledgements. This research was supported by the National Science Foundation (NSF) under grant number ATM-9113511. The computations were performed on the North Carolina Supercomputing Center (NCSC) Cray-T90, the on $F O A M^{\mathrm{V}}$ visualization and parallel computing facility at North Carolina State University, and on the National Center for Atmospheric Research (NCAR) Cray-T90 supercomputer. NCAR is sponsored by the NSF.

\section{LITERATURE CITED}

Acker TL, Buja LE, Rosinski JM, Truesdale JE (1996) User's guide to NCAR CCM3. NCAR Tech Note/TN-421+IA, Boulder, $\mathrm{CO}$

Allen JC, Barnes DF (1985) The causes of deforestation in developing countries. Ann Assoc Am Geogr 75:163-184

Bath LM, Rosinski J, Olson J (1992) User's guide to NCAR CCM2. NCAR Techn Note/TN-379+IA, Boulder, CO

Bonan GB (1996) A land surface model (LSM version 1.0) for ecological, hydrological, and atmospheric studies: technical description and user's guide. NCAR Techn Note/TN$417+$ STR, Boulder, CO

Brown R, Durning A, Flavin C, French H, Jacobson J, Lowe M, Postel S, Starke M, Young J (1990) State of the world 1990. A Worldwatch Institute report on progress toward a sustainable society. WW Norton and Company, New York

Brown LR, Denniston D, Flavin C, French H, Kane H, Lenssen N, Renner M, Roodman D, Ryan M, Sachs A, Starke L, Weber P, Young J (1995) State of the world 1995. A Worldwatch Institute report on progress toward a sustainable society. WW Norton and Company, New York

Bryan FO, Kauffman B, Large W, Gent P (1996) The NCAR CSM flux coupler. NCAR Tech Note NCAR/TN-424+STR, Boulder, $\mathrm{CO}$

Charney JG, Quirk WJ, Chow SH, Kornfield J (1977) A comparative study of the effects of albedo change on drought in semi-arid regions. J Atmos Sci 34:1366-1385

Cogley JG (1991) GGHYDRO-global hydrographic data release 2.0. Trent Climate Note 91-1, Dept. Geography, Trent University, Peterborough, ON

Dickinson RE, Henderson-Sellers A (1988) Modeling tropical deforestation: a study of GCM land-surface parameterizations. Q J R Meteorol Soc 114:439-462
Dickinson RE, Henderson-Sellers A, Kennedy PJ (1993) Biosphere-Atmosphere Transfer Scheme (BATS) version 1e as coupled to the NCAR Community Climate Model. NCAR techn Note NCAR/TN-387+STR, Boulder, CO

Eltahir E, Gong C (1996) Dynamics of wet and dry years in West Africa. J Clim 1030-1042

Goddard L, Graham NE (1999) The importance of the Indian ocean for GCM-based climate forecasts over eastern Africa and southern Africa. J Geophys Res 104:19099-19116

Gurney RJ, Foster JL, Parkinson CL (1993) Atlas of satellite observations related to global change. Cambridge University Press, Cambridge

Hack JJ, Boville BA, Briegleb BP, Kiehl JT, Rasch PJ, Williamson DL (1993) Description of the NCAR Community Climate Model (CCM2). NCAR Tech Note/TN-382 + STR, Boulder, $\mathrm{CO}$

Henderson-Sellers A, Gornitz V (1984) Possible climatic impacts of land cover transformations with particular emphasis on tropical deforestation. Clim Change 6:231-257

Holton JD (1972) An introduction to dynamic meteorology. Academic Press, New York

Hoskins BJ, Karoly D (1981) The steady linear response of a spherical atmosphere to thermal and orographic forcing. J Atmos Sci 38:1179-1196

International CLIVAR Project Office (2000) Climate Research for Africa. WCRP Informal Rep No. 16/1999; ICPO Publ Ser No. 29

IPCC WGII (1998) The regional impacts of climate change. An Assessment of vulnerability. In: Watson RT, Zinyowera MC, Moss RH (eds) Cambridge University Press, New York

Kalnay E, Halem M (1981) Large amplitude stationary Rossby waves in the southern hemisphere. Proceedings of the International Conference on early results of FGGE and large scale aspects of its monsoon experiments, Tallahassee. ICU/WMO, Geneva, p 3.5-3.15

Kalnay E, Kingtse M, Peagle J (1986) Large-scale amplitude short-scale stationary Rossby waves in the southern hemisphere: observations and mechanistic experiments to determine their origin. J Atmos Sci 43:252-275

Kiehl JT, Hack J, Bonan G, Boville B, Briegleb B, Williamson D, Rasch P (1996) Description of the NCAR Community Climate Model (CCM3). NCAR Techn Note NCAR/TN$420+$ STR, Boulder, CO

Krishnamurti TN, Ogallo LJ (1989) Recent african climate. Rep No. FSU-89-13, Florida State University, Tallahassee

Malingreau JP, Tucker CJ, Laporte N (1989) AVHRR for monitoring global tropical deforestation. Int J Remote Sensing 10:866-867

Matthews E (1983) Global vegetation and land use. J Clim Appl Meteorol 22:474-487

Nicholson SE, Kim J, Hoopingarner J (1988) Atlas of African rainfall and its interannual variability. Dept. of Meteorology, The Florida State University, Tallahassee

Nobre C, Sellers JP, Shukla J (1991) Amazonian deforestation and regional climate change. J Clim 4:957-988

Olson JS, Watts JA, Allison LJ (1983) Carbon in live vegetation of major world ecosystems. ORNL-5862, Oak Ridge National Laboratory, Oak Ridge, TN

Semazzi HFM (1980a) Stationary barotropic flow induced by a mountain over a tropical belt. Mon Weather Rev 108: 922-930

Semazzi HFM (1980b) Numerical experiments on the orographic dynamic phenomenon over a tropical belt. Arch Meteorol Geophys Biokl Ser A 29:55-65

Semazzi HFM, Sun L (1997) The role of orography in determining the Sahelian climate. Int J Climatol 17:581-596 
Semazzi HFM, Lin NH, Lin YL, Giorgi F (1993) A CCM1MM4 nested model study of the influence of sea-surface temperature anomalies on the Sahelian Climate. J Geophys L 20:2897-2900

Semazzi HFM, Burns B, Lin NH, Schemm JE (1996) A GCM study of the teleconnections between the continental climate of Africa and global sea-surface temperature anomalies. J Clim 9:2480-2497

Shukla J, Nobre CA, Sellers PJ (1990) Amazon deforestation and climate change. Science 247:1322-1325

Sud YC, Smith WE (1985) The influence of surface roughness of deserts on the July circulation. Boundary Layer Meteorol 33:15-49

Sud YC, Shukla J, Mintz Y (1988) Influence of land surface roughness on atmospheric circulation and precipitation: A sensitivity study with a general circulation model. J Appl Meteorol 27:1036-1054

Sun L, Semazzi FHM, Giorgi F, Ogallo L (1999a) Application of the NCAR Regional Climate Model to Eastern Africa. Part I: Simulations of Autumn Rains of 1988. J Geophys Res 104:6529-6548

Sun L, Semazzi FHM, Giorgi F, Ogallo L (1999b) Application of the NCAR Regional Climate Model to Eastern Africa. Part II: Simulations of interannual variability. J Geophys Res 104:6549-6562

Tucker CJ, Holben BN, Goff TE (1984) Intensive forest clear-

Submitted: October 20, 1999; Accepted: October 11, 2000 ing in Rondonia, Brazil, as detected by remote sensing. Remote Sensing Environ 15:255-262

Webb RS, Rosenzweig CE, Levine ER (1993) Specifying land surface characteristics in general circulation models: soil profile data set and derived water-holding capacities. Global Biogeochem Cycles 7:97-108

Williams M (1990) Forests transformed by human action: global and regional changes in the biosphere over the past 300 years. In: Turner BL et al. (eds) The earth as transformed by human action: global and regional changes in the biosphere over the past 300 years. Cambridge University Press, New York, p 179-201

Williamson DL, Rasch PJ (1989) Two-dimensional semiLagrangian transport with shape preserving interpolation. Mon Weather Rev 117:102-129

Zhang H, Henderson-Sellers A, McGuffie K (1996a) Impacts of tropical deforestation. Part I: Process analysis of local climate change. J Clim 9:1497-1517

Zhang H, McGuffie K, Henderson-Sellers A (1996b) Impacts of tropical deforestation. Part II: The role of large scale dynamics. J Clim 9:2498-2521

Zinyowera MC, Unganai SL (1993) Drought in southern Africa. An update on the 1991-92 drought. Drought Network News Int. 4(3):3-4

Zheng X, Eltahir E (1998) The role of vegetation in the dynamics of West African monsoons. J Clim 11:2078-2096

Proofs received from author(s): June 27, 2001 